\title{
First records of a new color pattern in the Goldblotch Grouper, Epinephelus costae (Steindachner, 1878) (Actinopterygii: Serranidae) and first record of leucism in the European conger, Conger conger (Linnaeus, 1758) (Actinopterygii: Congridae): a citizen science contribution
}

\author{
Francesco TIRALONGO ${ }^{1,2^{*}}$, Stefanos KALOGIROU ${ }^{3}$ and Igor AGOSTINI ${ }^{4}$ \\ ${ }^{1}$ Department of Biological, Geological and Environmental Sciences, \\ University of Catania, Catania, Italy \\ ${ }^{2}$ Ente Fauna Marina Mediterranea, Avola, Italy \\ ${ }^{3}$ Hellenic Centre for Marine Research, Hydrobiological Station of Rhodes, \\ 85100 Rhodes, Greece \\ ${ }^{4}$ Department of Humanities, University of Salento \\ *Corresponding author, : francesco.tiralongo@unict.it
}

In many fish, color patterns are striking features and can play an important role in both natural and sexual selection. Furthermore, details of color patterns are in some cases valid tools for species identification. However, fish can also show some genetic abnormalities, such as albinism and leucism. In this research, we report for the first time a new color pattern for Epinephelus costae (Steindachner, 1878), for which it is known an ontogenetic shift in color pattern, and the first case of leucism in Conger conger (Linnaeus, 1758).

Key words: Mediterranean Sea; color pattern; citizen science; abnormal coloration; coastal fish species

\section{INTRODUCTION}

Epinephelus costae (Steindachner, 1878) is one of the most intriguing species of the genus Epinephelus Bloch, 1793 as concerns the color. It is a demersal species, found in coastal waters between 1-200 $\mathrm{m}$ depth, more commonly at depth between 10 and $80 \mathrm{~m}$, on sandy, muddy and rocky bottoms (HEEMSTRA \& RANDALL, 1993; FROESE \& PAULY, 2020). The maximum reported standard length for this species is of $140 \mathrm{~cm}$ (FROESE \& PAULY, 2020). The most intriguing fea- tures of this fish are related to the color change between juveniles and adults, a point that is well described in the reference book of HEEMSTRA \& RANDALL (1993): «Juveniles less than $15 \mathrm{~cm}$ standard length with 3 to 5 narrow dark stripes (possibly blue in life) paralleling lateral line on dorsal part of body: 2 stripes above and 1 to 3 stripes below the lateral line. Two dark lines on head: one from the lower edge of eye to the ventral rear edge of inter-opercle, the second from dark maxillary streak to the lower edge of the preopercle. Adults are brown or greyish brown, 
often with a large, distinct golden yellow blotch (vaguely defined at periphery) on body below spinous dorsal fin».

The fundamental point is that a chromatic variation takes place during the life of this proterogynic fish: the stripes of juveniles are succeeded by the yellow blotch of the adults. Now, it is precisely the discovery of this variation who leaded the biologists to accept unification under the name $E$. costae of phenotypes which in the past had been classified under different species because of the ignorance of such ontogenetic color pattern variation.

A decisive step in this history was marked by DODERLEIN (1882), who argued that the three presumed species namely Serrauns costae Steindachner, 1878 (name taken from COSTA, 1850), Serranus alexandrinus Valenciennes, 1828, both characterized by more or less developed horizontal stripes, and Cerna chrysotaenia Döderlein, 1882, characterized by a yellow blotch, were the three developmental stages of a single species.

The phenomenon of the yellow blotch was later studied in more detail by two Italian scholars, BINI (1960) and, especially, TORCHIO (1963), who established three additional points:

1. The yellow blotch which can be observed in fish of a minimum total length of $35 \mathrm{~cm}$;

2. In living specimens, the color changes underwater and, specifically, the horizontal stripes turn into a yellow blotch, and conversely, the yellow blotch turns into stripes in a few minutes;

3. The yellow blotch tends to disappear post mortem.

More recently, AGOSTINI \& PURETTI (2018) developed this point arguing that: 1) the presence of the yellow blotch in E. costae is a reversible phenomenon not only in live specimens, but also in dead ones; 2) the blotch can appear post mortem also in specimens which, when alive in the sea, did not present the blotch. However, this is not the whole story.

We think that another feature concerning the color of E. costae should be added, one which was until now not yet reported in the scientific literature. A similar feature was largely documented in Epinephelus marginatus (Lowe, 1834), especially as concerns juvenile specimens: the presence of yellow star-shaped blotches on body and head, mostly arranged in vertical series (they are at the origin the vernacular name of Cernia stiddata in Santa Maria di Leuca; see AGOSTINI, 2018).

The European conger, Conger conger (Linnaeus, 1758) is a common benthic species of rocky and sandy bottoms of the northeastern Atlantic and Mediterranean Sea, where it is the only representative of the genus. It can reach a maximum total length of $300 \mathrm{~cm}$, but common sizes are of about 100-150 cm (FROESE \& PAULY, 2020). It is usually found between 0-500 $\mathrm{m}$ depths, but it has been found at a depth of $1171 \mathrm{~m}$ (MYTILINEOU et al., 2005). Females are larger than males (CASADEVALL et al., 2017). The typical color pattern of this species consists of an almost uniform light grey to blackish body, with a whitish ventral part. Lateral line pores are white and the distal margins of the dorsal and anal fins are blackish (COSTA, 1991). Mature females undergo a deep transformation in color and morphology (i.e. an almost uniformly black body color, trapezoidal and very short pectoral fin and larger eyes) when reaching the final life stage (BATTAGLIA et al., 2019).

We report the first observation of a large specimen of $C$. conger affected by leucism.

\section{MATERIAL AND METHODS}

On $30^{\text {th }}$ May 2020, two specimens of $E$. costae with a total length (TL) of about 35 and $50 \mathrm{~cm}$ were caught with trolling line at Alimini, Otranto (Adriatic Sea), at a depth of about 22 $\mathrm{m}$ (Fig. 1). Both specimens showed a curious color pattern, never described in literature so far. Another specimen of E. costae of about $40 \mathrm{~cm}$ TL with a similar color pattern was observed and photographed in situ on $19^{\text {th }}$ May 2020 at Pellaro (Calabria, Strait of Messina), at a depth of about 20 m (Fig. 1).

On $24^{\text {th }}$ September 2020, a white conger eel weighing $12.5 \mathrm{~kg}$ was caught $\mathrm{NE}$ off the Andros Island (Aegean Sea) with hand-line by a commercial fisherman at a depth of $280 \mathrm{~m}$. 


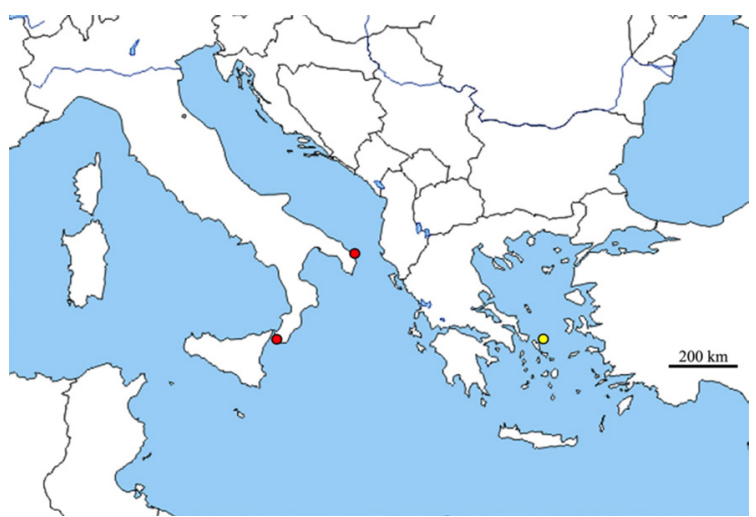

Fig. 1. Study area in the central (Italy) and eastern (Greece) Mediterranean Sea. Red circles indicate locations where the specimens of Epinephelus costae were caught (Alimini, Adriatic Sea) and photographed in situ (Pellaro, Strait of Messina); the yellow circle indicates the location where the white specimen of Conger conger was caught (Andros Island, Aegean Sea)

Unfortunately, the fish was sold at the market and further detailed analyses were not possible.

Fishermen and the underwater photographer were interviewed in order to collect additional and useful details for a better description of the records.

\section{RESULTS AND DISCUSSION}

As in normal specimens, the background body color of the two specimens of E. costae collected at Alimini was dark brown on the dorsal area, and gradually lightened towards the ventral surface, becoming grayish on belly. However, we observed for the first time the presence of irregular yellow blotches, organized in four irregular slightly oblique stripes, extended from the dorsal surface up to about half height of sides. The first extended from the first three spines of the dorsal fin to the superior part of the opercle; the second one extended between the $6^{\text {th }}$ and $8^{\text {th }}$ dorsal spine to the height of the posterior and superior part of the pectoral fin; the third one extended from the $1-4^{\text {th }}$ soft dorsal rays to about half body height on sides; the fourth one extended from the last soft rays of the dorsal fin and part of the caudal peduncle to almost the ventral part of the body. Furthermore, some irregular yellow blotches were present on the dorsal area of the head (Fig. 2a). The smaller

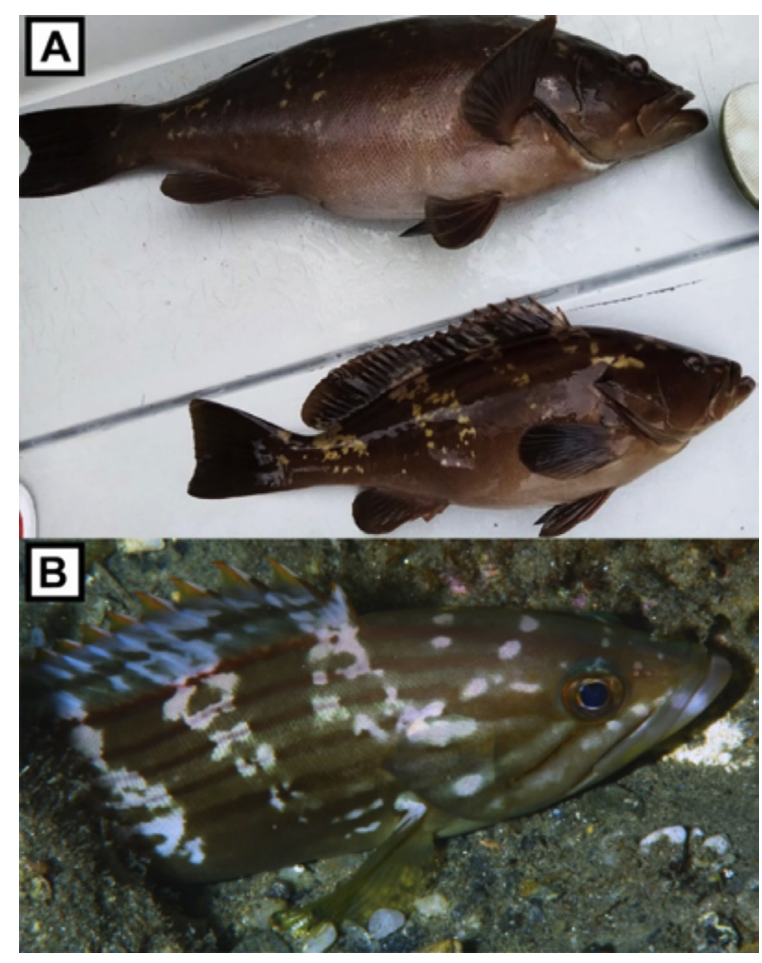

Fig. 2. The two specimens of E. costae collected at Alimini (Adriatic Sea) on 30 $0^{\text {th }}$ May 2020 (A) and the specimen photographed at Pellaro (Strait of Messina) on $19^{\text {th }}$ May 2020 (B)

specimen showed, although not clearly visible, the typical longitudinal dark bars of the species. The specimen photographed at Pellaro was initially misidentified by the photographer as E. marginatus because the presence of "strange white-grayish vertical bars", similar to those of E. marginatus and equal (but of different color) to those observed in the specimens of $E$. costae caught at Otranto (Fig. 2b). However, after the examination of the photos by authors, the fish was easily identified as E. costae because the presence of its typical longitudinal dark stripes. To the best of our knowledge, this is the first work showing this "atypical" color pattern in E. costae: four slightly oblique (almost vertical) blotched yellow or white-grayish bars were present on body, similarly as is commonly known in the typical color pattern of juveniles of E. marginatus, although they may also be present in some adult specimens. Although this particular coloration seems rare, further studies are necessary in order to assess how spread is 


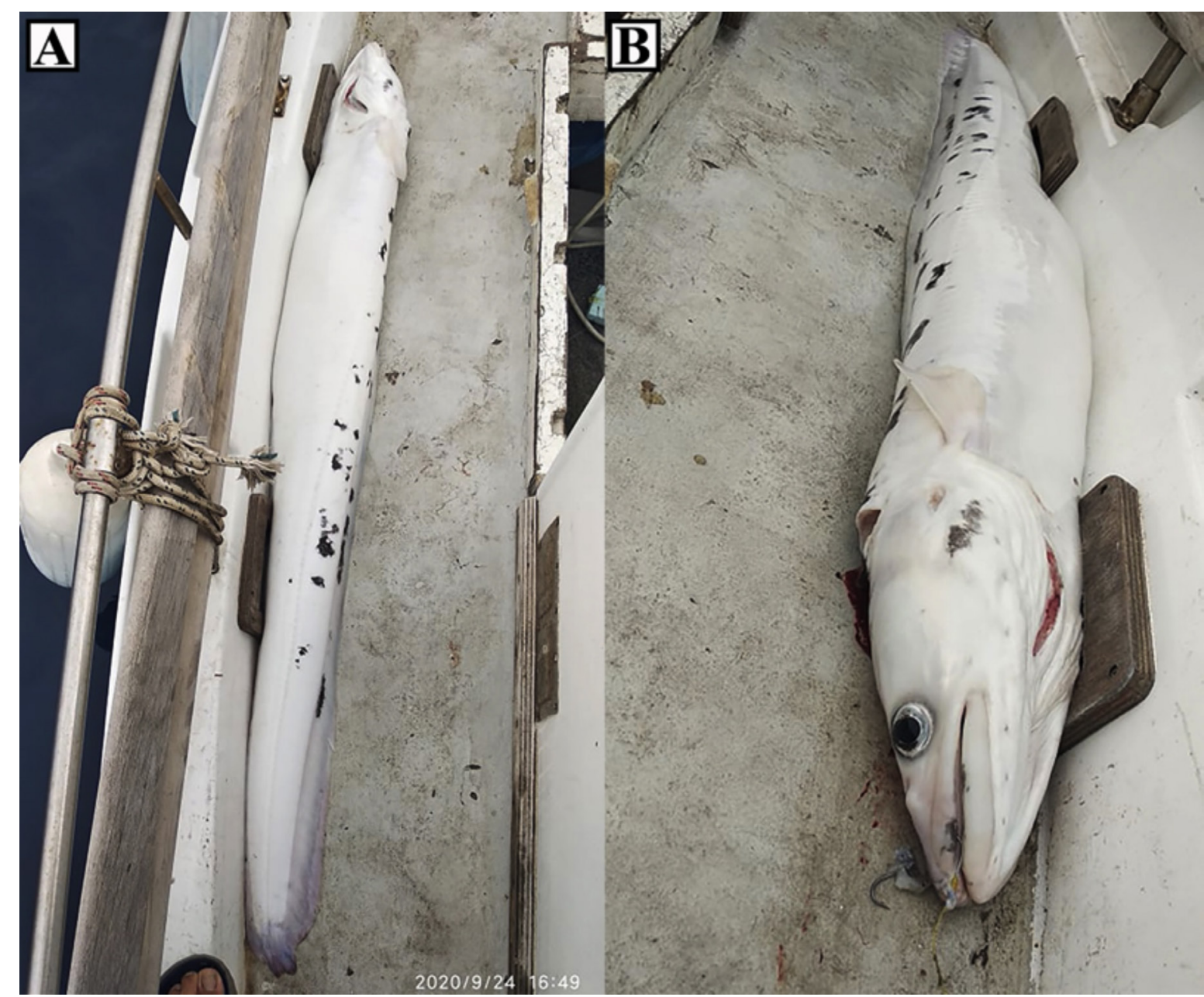

Fig. 3. The white specimen of $\mathrm{C}$. conger (A) collected NE off the Andros Island (Aegean Sea) on $24^{\text {th }}$ September 2020 and particular of the head $(B)$

this phenomenon and its relationships with size, environmental factors and/or genetics. However, a curious fact is that this characteristic was never reported in literature.

The white conger eel caught NE off the Andros Island was almost uniformly white (Fig. 3a) and with some doubts it was correctly recognized by the fisherman as an European conger, $C$. conger, considering the typical morphological features of this species. The fish was still alive when taken on board and the white color was maintained also after death. Considering that the eyes showed the normal color of $C$. conger (Fig. $3 \mathrm{~b}$ ), rather than reddish shades (typical of true albinism), and the fact that the distal part of the dorsal and anal fins was light grey in color, we are faced with a case of leucism (partial albino) rather than albinism (VEENA et al., 2011). In all the observed cases, these phenomena are generally attributed to genetic mutation (SANCHES et al., 2019). To the best of our knowledge, this is the first case of leucism in C. conger. Furthermore, from photo, the tail of the specimen seems to be bifid, but unfortunately the fish was sold at the market and we have not been able to further investigate this other aspect. Although reported in several species of teleosts and elasmobranchs, leucism can be considered a relatively rare phenomenon. As regards the order Anguilliformes, an abnormal white anguillid eel, Anguilla bengalensis (Gray, 1831), was caught in the Perak River (Malaysia), and an abnormal white moray eel of the species Muraena clepsydra Gilbert, 1898, was caught in the Pacific Ocean (Ecuador) 
(BÉAREZ, 2002; KADIR et al., 2015). Although in some species the presence of albinism and leucism could reduce the survival capability due to predation, in nocturnal and benthic (or cryptic) species (as in the case of our specimen of $C$. conger) these abnormalities seem to have little influence (SAMPAIO et al., 2015). Indeed, considering the weight of our specimen $(>12 \mathrm{~kg})$, the fish managed to survive in its environment for several years (MATIĆ-SKOKO et al., 2012).

In conclusion, we report for the first time a new color pattern for E. costae, adding it to those already known for the species. In consideration of this, we can consider the color of this species quite variable and this new character, when present, should be taken in consideration for the identification of the species, in order to avoid misidentification with similar species during researches (e.g. visual census, fishery studies, analysis of photos/videos). As regards the first case of leucism for C. conger here reported, further analysis would have been helpful to better understand which factors are responsible of such color variations in the fish, and to elaborate on the still poorly understood cases of leucism and albinism in general. We also highlight the role of citizen science in the Mediterranean Sea not only for the monitoring biodiversity and ecological changes, but also for the discover of new behavior, species association and morphochromatic traits (TIRALONGO et al., 2019; TIRALONGO et al., 2020).

\section{ACKNOWLEDGEMENTS}

We are grateful to Luigi Puretti and Santo Tirnetta for providing us the photos of Epinephelus coastae and to Giorgos Darzentas, fisherman in Andros, Greece for providing us the photos of Conger conger through WWF Greece.

\section{REFERENCES}

AGOSTINI, I. 2018. Nomenclature dialettali delle specie dei generi Epinephelus, Mycteroperca, Polyprion nel mare del Salento. Palaver, 7: 117-204.

AGOSTINI, I. \& L. PURETTI. 2018. Annotations on the post-mortem disappearance of the yellow blotch on Epinephelus costae (Steindachner, 1878). Thalassia Salentina, 40: 3-7.

BATTAGLIA, P., D. SMITH, G. AMMENDOLIA, M. CAVAllaro, T. MAGGio, P. CONSOLI, M.C. GUERRERA, F. ANDALORO \& T. ROMEO. 2019. The last stage in the life history of the European conger eel Conger conger: a transformation before death. Journal of Fish Biology, 96(2): 533-538.

BÉAREZ, P. 2002. First record of albinism in a moray eel, Muraena clepsydra (Muraenidae) from Ecuador. Cybium, 26: 159-160.

BINI, G. 1960. Sull'identità della Cerna chrysotaenia Doderlein. Bollettino di pesca, piscicoltura e idrobiologia, 36: 225-236.

CASADEVALL, M., L. SARRÀ-ALARCÓN, E. DELGADO \& J. MATALLANAS. 2017. The sexual segregation of the European eel, Conger conger (Linnaeus, 1758) (Anguilliformes, Congridae) and female semelparity in the Northwest Mediterranean. Journal of Fisheries Research, 1(1): 5-14.

COSTA, F. 1991. Atlante dei pesci dei mari italiani. Mursia, Milano, pp. 438.

COSTA, O. G. 1850. Fauna del Regno di Napoli: ossia enumerazione di tutti gli Animali, che abitano le diverse regioni de questo regno e le acque che le bagnano, contenente la descrizione de' nuovi o poco esattamente conosciuti. Parte Prima. Pesci. Azzolino, Napoli, pp. 1829-1886.

DODERLEIN, P. 1882. Riviste del genere Epinephelus o Cerna Bp. riscontrate sin'ora nei mari della Sicilia. Giornale di Scienze Naturali ed Economiche di Palermo, 15: 1-96.

Froese, R. \& D. PAULY. 2020. FishBase. www. fishbase.org. Accessed in October 2020.

HEEMSTRA, P.C. \& J.E. RANDALL. 1993. Groupers of the World (family Serranidae, subfamily Epinephelinae): An Annotated and Illustrated Catalogue of the Grouper, Rockcod, Hind, Coral Grouper and Lyretail Species known 
to date, Food and Agriculture Organization of the United Nations, Rome, pp. 382.

KADIR, S.R.A., M.H.F.A. RASID, L.L. WONG, K.O. KWONG \& T. ARAI. 2015. First record of albinism in a tropical anguillid eel Anguilla benegalensis benegalensis from Malaysia. Marine Biodiversity Records, 8: e114.

MATIĆ-SKOKO, S., J. FERRI, P. TUTMAN, D. SKARAMUCA, D. DIKIĆ, D. LISICIĆ, Z. FRANIĆ \& B. SKARAMUCA. 2012. The age, growth and feeding habits of the European conger eel, Conger conger (L.) in the Adriatic Sea. Marine Biological Research, 8: 1012-1018.

MYTILINEOU, C., C.-Y. POLITOU, C. PAPACONSTANTINOU, S. KAVADAS, G. D'ONGHIA \& L. SION. 2005. Deep-water fish fauna in the Eastern Ionian Sea. Belgian Journal of Zoology, 135(2): 229-233.

SAMPAIO, C.L.S., J.C.C. NUNES \& R.M. MACIEIRA. 2015. First record of colour abnormalities in the bocon toadfish Amphichthys cryptocentrus (Valenciennes 1837) Teleostei: Batrachoididae). Marine Biodiversity Records, 8: e136.

SANCHES, P.R., F.P. SANTOS \& C.E. COSTA-CAMPOS. 2019. First record of leucism in Tropidurus hispidus (Spix, 1825) (Squamata: Tropiduridae) in north Brazil, Eastern Amazon. Acta Zoologica Mexicana, 35: 1-4.

TIRALONGO F., F. RUSSO \& M. COLOMBO. 2019. From scuba diving to social networks: a curious association between two small fish species, Lepadogaster candolii Risso, 1810 and Parablennius rouxi (Cocco, 1833), and Muraena helena (Linnaeus, 1758) coming from citizen science. Regional Studies in Marine Science, 29: 100648.

TIRALONGO F., F. CROCETTA, E. RIGINELLA, A.O. LILLO, E. TONDO, A. MACALI, E. MANCINI, F. RUSSO, S. COCO, G. PAOLILLO \& E. AZZURRO. 2020. Snapshot of rare, exotic and overlooked fish species in the Italian seas: a citizen science survey. Journal of Sea Research, 164: 101930.

TORCHIO, M. 1963. Sulla mutabilità della colorazione in Epinephelus alexandrinus (Cuv. Val.) 1828 (Osteichtyes Serranidae). Natura: rivista di Scienze Naturali, 54: 1-7.

VEENA, S., S. THOMAS, S.G. RAJE \& N.R. DURGEKAR. 2011. Case of leucism in the spadenose shark, Scoliodon laticaudus (Müller and Henle, 1838) from Mangalore, Karnataka. Indian J. Fish., 58(1): 109-112.

Received: 19 October 2020

Accepted:18 February 2021 
Prvi zapis o novoj obojanosti kirnje zlatice, Epinephelus costae (Steindachner, 1878) (Actinopterygii: Serranidae) i prvi zapis o leucizmu ugora, Conger conger (Linnaeus, 1758) (Actinopterygii: Congridae): građanski doprinos znanosti

\author{
Francesco TIRALONGO, Stefanos KALOGIROU i Igor AGOSTINI \\ *Kontakt e-pošta: francesco.tiralongo@unict.it
}

\begin{abstract}
SAŽETAK
Kod mnogih riba obojanost ima upečatljiva obilježja i može igrati važnu ulogu kako u prirodnom tako i u spolnom odabiru. Detalji o uzorcima boja u nekim su slučajevima valjani alat za identifikaciju vrsta. Međutim, riba može pokazati i neke genetske abnormalnosti, poput albinizma i leucizma. U ovom istraživanju prvi put izvješćujemo o novoj obojanosti Epinephelus costae (Steindachner, 1878.) i o prvom slučaju leucizma kod ugora, Conger conger (Linnaeus, 1758),
\end{abstract}

Ključne riječi: Sredozemno more; obojanost; građanska znanost; abnormalna obojenost; obalne vrste riba 
